\title{
An Outbreak of Staphylococcal Food Poisoning in the Municipality of Passos, Mg, Brazil
}

\author{
Luiz Simeão do Carmo¹, Ricardo Souza Dias², Valter Roberto Linardi ${ }^{3 *}$, Maria José de \\ Sena $^{1}$ and Deise Aparecida dos Santos ${ }^{1}$ \\ ${ }^{I}$ Fundação Ezequiel Dias; Laboratório de Enterotoxinas; Belo Horizonte - Minas Gerais - Brazil. ${ }^{2}$ Fundação \\ Ezequiel Dias; Serviço de Microbiologia de Alimentos; Belo Horizonte and Unicentro Izabela Hendrix, Belo \\ Horizonte, Minas Gerais - Brazil. ${ }^{3}$ Departamento de Microbiologia; ICB UFMG; linardiv@mono.icb.ufmg.br;C. P. \\ 486; 31270-901; Belo Horizonte - Minas Gerais - Brazil
}

\begin{abstract}
An outbreak of staphylococcal food poisoning involving 42 people who had eaten a meal at a restaurant in the Municipality of Passos, Minas Gerais, Brazil, is reported. Thirty-one of the individuals became ill with vomiting, diarrhea and dizziness within 30 minutes after eating the meal. The foods suspected were: chicken pancake, rice, beans, tomato sauce and mashed chick-peas. Large numbers $\left(\geq 2.0 \times 10^{8} \mathrm{CFU} / \mathrm{g}\right)$ of enterotoxigenic staphylococci were present in the chicken pancake. These strains produced enterotoxins $A, B$ and D. Swabs from the nasal cavity and throat and from under the fingernails of food handlers were cultured for the detection of enterotoxigenic staphylococci carriers. Four out of five of them were healthy carriers of enterotoxin A, B, C and D producing Staphylococcus aureus at the sites cultured and one of them was also a nasal carrier of TSST-1 toxin producing S. aureus. These results indicate that the food handlers would have been the source of the food contamination.
\end{abstract}

Key words: Staphylococcal enterotoxin, food poisoning, staphylococci, food handlers

\section{INTRODUCTION}

Among foodborne pathogenic microorganisms commonly encountered in food poisoning outbreaks, enterotoxigenic staphylococci have been isolated at high frequency $(5,8)$. Bakery goods covered and filled with cream are leading causes of food poisoning worldwide $(1,13,14$, $16)$, and so are different types of meat, seafood, dairy products and mayonnaise $(10,11)$. Staphylococcal enterotoxins induce food poisoning after the consumption of food containing enterotoxin produced by the growth of coagulase-positive staphylococci in food especially some strains of S. aureus. Although there are some reports about isolation of coagulase-negative enterotoxin producers, very little information is available about food poisoning caused by coagulase-negative staphylococci $(6,7$, 19, 25).

In recent years, many cases of staphylococcal food poisoning have occurred in Minas Gerais state. However, very few cases have been notified, and therefore the statistics do not reflect the real incidence of illnesses transmitted by food. This has resulted in the establishment of a Staphylococcus laboratory at Fundação Ezequiel Dias. This laboratory is primarily intended to produce and purify the reagents necessary for use in the investigation of staphylococcal enterotoxin

\footnotetext{
* Author for correspondence
} 
outbreaks. A thorough investigation of these outbreaks has not been done because they are not of compulsory notification, and so no investigation has been conducted to determine the source of contamination. It should also be considered that in some cases the symptoms are mild and the people involved do not look for medical care $(1,9,10)$.

In the past, isolation of the microorganism from food incriminated in a food poisoning outbreak was the only evidence of its involvement. Nowadays specific methodologies are being used for the identification of the enterotoxins produced by microorganism and the direct detection of toxins in food is frequently the procedure of choice to determine the causative agent of foodborne outbreak. Humans are the main source of the microorganisms, which are found in about $30 \%$ to $50 \%$ of the population. Staphylococci can be present in the throat, nasal area and also under the fingernails as commensal inhabitants. Mori et al. (20) showed that $22 \%$ of food handlers studied were carriers of enterotoxigenic S. aureus (88/400). Carmo et al. (12), testing for the production of enterotoxin by strains of staphylococci isolated from food handlers involved in an outbreak at a restaurant in Brasilia, Brazil, found that several handlers were colonized with enterotoxigenic staphylococci at different sites.

Raw food can bear a high variety of microorganisms that are eliminated by high cooking temperatures $(1,3)$. Dias et al. (14), while investigating an outbreak, detected the presence of staphylococcal enterotoxins $\mathrm{C}$ and $\mathrm{D}$ in the suspected food (a kind of tart without a covering and with no filling) but the cell counts were less than $100 \mathrm{CFU} /$ gram of food, suggesting that the microorganisms were eliminated by the high cooking temperature. However, food analysis indicated the presence of enterotoxins in the implicated food, due to the thermal resistance of these toxins. The objective of the present study was to identify the cause of an outbreak by contaminated food in the municipality of Passos, MG, Brazil.

\section{MATERIALS AND METHODS}

\section{Description of the outbreak}

An outbreak of staphylococcal food poisoning involving 42 people in the Municipality of Passos was notified. The suspected foods were chicken pancake, rice, beans, tomato sauce and mashed chick-peas prepared at a local restaurant. According to information, 42 people ate the meal, 31 of them became sick and six needed medical care in a hospital. The food was prepared in the morning and kept in containers on low heat to keep it warm until midday, when it was served. Typical symptoms of staphylococcal food poisoning, such as dizziness, vomiting, cramps and diarrhea, occurred within thirty minutes after food ingestion.

\section{Sample collection}

After notification, Sanitary Inspectors of the Municipality began the investigation of the outbreak. Analysis of the data suggested that the outbreak was due to the consumption of staphylococcal enterotoxins in the food, and therefore samples of foods leftovers were collected. To determine the possible source of contamination, samples from the nostrils, throat and fingernails of the food handlers were obtained using sterile swabs. The food leftovers were kept under refrigeration and the swabs inoculated in Triptic Soy Broth (TSB) with $10 \%$ sodium chloride. These materials were sent to the Food Microbiology Laboratory of FUNED for analysis.

\section{Isolation of staphylococci from foods}

According to the method of Lancette and Tatini (18), $25 \mathrm{~g}$ of each implicated food were homogenized with in $225 \mathrm{~mL}$ of $0.1 \%$ buffered peptone water. A $0.1 \mathrm{~mL}$ aliquot of the suspension was then spread on the surface of a Baird-Parker agar plate. Additional plates were prepared with successive decimal dilutions. The plates were incubated for 48 hours at $37^{\circ} \mathrm{C}$, and the suspected colonies were counted. Ten typical colonies (jet black to dark grey, smooth, convex, well-defined contours, off-white edge, presenting an opaque zone and/or a clear halo beyond the opaque zone) and 10 colonies classified as atypical (gray and mucoid showing one halo) were transferred to tubes containing nutrient agar (stock culture) for further testing.

\section{Isolation of staphylococci from food handlers}

Each swab collected from the nasal cavity, throat and from under the fingernails was introduced in tubes containing $5 \mathrm{~mL}$ of Triptic Soy Broth (TSB) with $10 \%$ of $\mathrm{NaCl}$. The tubes were incubated for $24 \mathrm{~h}$ at $37^{\circ} \mathrm{C}$. The cultures were streaked on BairdParker plates and incubated for 48 hours at $37^{\circ} \mathrm{C}$. 
Ten typical and 10 atypical colonies were selected for further testing as described above.

\section{Biochemical characterization of isolated colonies}

Each colony was transferred from nutrient agar to two separate test tubes containing $1 \mathrm{~mL}$ of $\mathrm{BHI}$ broth and incubated for 24 hours at $37^{\circ} \mathrm{C}$. Tests for coagulase and thermonuclease (TNase) production, anaerobic fermentation of glucose and manitol, and hemolysin production using sheep blood were carried out according to Lancette and Tatini (18).

\section{Enterotoxin production}

Inocula were prepared from each isolated colony by incubating the staphylococci in Brain Heart Infusion (BHI) broth overnight at $37^{\circ} \mathrm{C}$. Membrane-over-agar plates were prepared with 25 $\mathrm{mL}$ of BHI agar and covered with a membrane disk made from Spectra/membrane dialysis tubing, 6000-8000, $100 \mathrm{~mm}$ flat width (Thomas Scientific, Philadelfia, PA USA) Robbins et al. (23). The membrane was inoculated with $0.5 \mathrm{ml}$ of the inoculum and the plates were incubated at $37^{\circ} \mathrm{C}$ for 24 hours. The cultures were removed from the membranes by washing with $2.5 \mathrm{~mL}$ of $0.02 \mathrm{M} \mathrm{NaHPO}_{4}$ in two steps using $1,5 \mathrm{~mL}$ and 1 $\mathrm{mL}$ of the buffer. The cultures were centrifuged and culture supernatant fluids were used for enterotoxin testing $(23,24)$.

\section{Enterotoxin testing}

The Optimum-Sensitivity-Plate (OSP) method of Robbins et al. (23) was used. Three $\mathrm{ml}$ of Noble agar $(1.2 \%)$ was prepared in $0.02 \mathrm{M}$ PBS, $\mathrm{pH} 7.4$ and $1 \mathrm{ml}$ of Timerosal 1.1000 was added as preservative. The agar was placed in $50 \mathrm{~mm}$ diameter plastic Petri dishes with tight. Five 8.3 $\mathrm{mm}$ diameter and two $6.7 \mathrm{~mm}$ diameter wells were cut in the agar. Specific antiserum was placed in the central well, enterotoxin $(4 \mu \mathrm{g} / \mathrm{mL})$ was placed in the two smaller wells, and culture supernatant fluids were placed in the four larger outer wells. Positive reactions were indicated by preciptin lines formed by the culture supernatant fluids that join the control lines. Each enterotoxin was tested in different dish. The dishes were placed in a humidified container and incubated overnight at $37^{\circ} \mathrm{C}$.

\section{RESULTS AND DISCUSSION}

In recent years, much attention has been given to food production, processing, packaging, transportation and storage. Therefore when foods are not produced and stored in proper conditions and or if any kind of damage occurs, they may be contaminated with infectious or toxigenic microorganisms, thus becoming a source of illness for humans. Over the last few years, staphylococcal food poisoning outbreaks have been recognized and investigated in Brazil. (10, $11,14)$. Initially, only the isolation of staphylococci from the suspected food was performed, representing circumstantial evidence that the illnesses might have been caused by staphylococcal enterotoxins inducing the symptoms characteristic of this type of food poisoning. Later, the staphylococci were tested for enterotoxin production the cause of the poisoning. Finally, the foods were examined for the presence of enterotoxin to indicate that the illnesses were due to staphylococcal food poisoning $(11,12)$. According to Evenson et al. (15), $100 \mathrm{ng}$ to $200 \mathrm{ng}$ of staphylococcal enterotoxin $\mathrm{A}$ is enough to induce the symptoms of food poisoning in humans. Among the foods incriminated in this food poisoning outbreak, enterotoxigenic staphylococci were only isolated from chicken pancake in relatively large numbers, i.e., more than $2.0 \times 10^{8} \mathrm{CFU} / \mathrm{gram}$ of food.

The test for enterotoxin production showed that the strains isolated from the implicated food were producers of enterotoxins SEA, SEB and SED (Table 1).

One aspect in the investigations of food poisoning outbreaks is to determine how the implicated food become contaminated. It is recognized that food handlers are the major

source of contamination with staphylococci $(5,11$, $12,17,23,24,25)$. High frequency of carrier status among food handlers has been identified by several investigators and many investigation studies conducted on staphylococci carrier status in humans in many countries, including Brazil (2, $4,10,12,17,20,21,22)$ showed that 30 to $50 \%$ of them were carriers at any given time. Pereira et $a l$. (22) examined 55 healthy food handlers in a large industrial kitchen in Belo Horizonte (Brazil) and found that $32(58.2 \%)$ were carriers of $S$. aureus and $17(30.9 \%)$ carried enterotoxigenic strains in their nose, throat and under fingernails. In the present study, four of five food handlers were 
found to be colonized by enterotoxigenic staphylococci. Food handler 1 had SED-producing strains in the throat and SEC and SED-producing strains in the nose. The nose of food handler 2, was colonized only with SED-producing strains, while food handler 3, was colonized with SEB and SEC-producing strains in only one site (nose). Besides colonized with SEA and SED producing strains, the nose of food handler 5 also had TSSTproducing strains.

These four food handlers were nasal carriers and only one of them was colonized at two sites, throat and nose (food handler 1), as shown in Table 2.
Table 1 - Staphylococcal count and enterotoxins in food associated with a food poisoning outbreak in the municipality of Passos - MG (Brazil).

$\begin{array}{ccc}\begin{array}{c}\text { Food } \\ \text { involved }\end{array} & \begin{array}{c}\text { Staphylococcal } \\ \text { count }\left(\text { CFU } / \mathbf{g}^{\mathbf{a}}\right)\end{array} & \begin{array}{c}\text { Enterotoxin } \\ \text { Detected by OSP }\end{array}\end{array}$

$\begin{array}{lcc}\begin{array}{l}\text { Chicken } \\ \text { pancake }\end{array} & \text { A, B, D } \\ \begin{array}{l}\text { Rice } \\ \text { Bean }\end{array} & <100 & (-) \\ \text { Tomato } & <100 & (-) \\ \begin{array}{l}\text { Sauce } \\ \text { Mash of } \\ \text { chick-pea }\end{array} & (-) \\ { }^{\mathrm{a} C F U-\text { Colony Forming Unit }} \\ { }^{\mathrm{b} \text { OSP- Optimum Sensitivity Plate }}\end{array}$

$\underline{\text { Table } 2 \text { - Enterotoxigenic staphylococci in food handlers. }}$

\begin{tabular}{|c|c|c|c|c|c|c|}
\hline \multirow{2}{*}{$\begin{array}{c}\text { Food } \\
\text { Handl } \\
\text { er } \\
\end{array}$} & \multicolumn{2}{|c|}{ Throat } & \multicolumn{2}{|c|}{ Fingernail } & \multicolumn{2}{|c|}{ Nasal } \\
\hline & SET & TSST & SET & TSST & SET & TSST \\
\hline 1 & D & $(-)$ & $(-)$ & $(-)$ & $C, D$ & $(-)$ \\
\hline 2 & $(-)$ & $(-)$ & $(-)$ & $(-)$ & $\mathrm{D}$ & $(-)$ \\
\hline 3 & $(-)$ & $(-)$ & $(-)$ & $(-)$ & $B, C$ & $(-)$ \\
\hline 4 & $(-)$ & $(-)$ & $(-)$ & $(-)$ & $(-)$ & $(-)$ \\
\hline 5 & $(-)$ & $(-)$ & $(-)$ & $(-)$ & A, D & $(+)$ \\
\hline
\end{tabular}

SET- Enterotoxin Produced, TSST- Toxic Shock Syndrome Toxin, (-) negative, (+) positive

An explanation for the fact that one of the strains isolated from one of the food handlers was a SEC producer, while the strains from food were not, could be that only ten colonies were picked from each plate, and perhaps the SEC-producing strain may have been missed in food.

The search for foodborne pathogenic microorganisms is a common practice at the Public Health Laboratory, but examination for food handlers is sometimes neglected during the investigation of an outbreak. Food handlers must be considered a potential source of enterotoxigenic staphylococci, and the identification of the enterotoxin produced by strains isolated from both food handler and incriminated food will help trace the agent's profile.

Although in some countries individuals colonized with staphylococci are not allowed to handle food, this is not a practical solution to the problem, because it is difficult to control. The best solution is the proper training of food handlers in order to prevent the contamination of vulnerable foods, and to instruct them on the need of proper storage of such foods. In addition, foods should be kept either above $45^{\circ} \mathrm{C}$ or below $4^{\circ} \mathrm{C}$ during storage so any staphylococci present will not be able to grow and produce enterotoxin $(6,8,9,16)$.

\section{ACKNOWLEDGEMENTS}

We wish to acknowledge the technical assistance of Leoneide Erica Maduro Bouillet, and Dr. Rogério Queiróz da Silva, head of the Sanitary Division of the Municipality of Passos-MG for the epidemiological investigation of this outbreak.

\section{RESUMO}

Um surto de toxinfecção alimentar envolvendo 42 pessoas, ocorrido após a ingestão de uma refeição 
servida num restaurante do município de Passos, Minas Gerais, Brasil, é relatado. Trinta minutos após a ingestão dos alimentos, 31 pessoas adoeceram apresentando tontura, vômito, cólica e diarréia. Os alimentos suspeitos foram panqueca de frango, arroz, feijão, molho de tomate e pasta de grão de bico. Foram isolados na panqueca de frango contagens superiores a $2,0 \times 10^{8}$ UFC de estafilococos produtores de enterotoxinas A, B e D por grama do alimento. Culturas isoladas a partir da região orofaríngea, sub-ungüeal e mucosa nasal dos manipuladores de alimentos revelaram serem estes, portadores assintomáticos de cepas de $\mathrm{S}$. aureus produtores de enterotoxinas A, B, C e D. $\mathrm{Na}$ mucosa nasal de um dos manipuladores foi isolada a cepa de S. aureus produtora de TSST-1. Os resultados obtidos indicam os manipuladores como prováveis fontes de contaminação dos alimentos.

\section{REFERENCES}

Anunciação, L. L. C.; Linardi, V. R.; Carmo, L. S. and Bergdoll, M. S. (1995), Production of staphylococcal enterotoxin A in cream-filled cake. Rev. Microbiol., 26, 259-263.

Adesium, A. A.; Webb, L. A. and Romain, H. T. (1998), Prevalence and characteristics of Staphylococcus aureus strains isolated from bulk and composite milk and cattle handlers. J. Food. Protec., 61, 629-632.

Akhtar, M.; Park, C. E. and Raiman, K. (1996), Effect of ureia treatment on recovery of staphylococcal enterotoxin A from heat-processed. Food Appl. Environ. Microbiol., 62, 3274-3276.

Araújo, M. A.; Uthida-Tanaka, A. M. and Castro, O. C. (1985), Staphylococcus aureus II prevalência em portadores sãos e pacientes com conjuntivite estafilocócica. Rev. Microbiol., 16, 41-45.

Arbuthnott, J. P.; Coleman, D. C. and Azevedo, J. S. (1990) Staphylococcal toxins In: Human Disease. J. Appl. Bacteriol. Symposium Supplement. pp. 101S-107S.

Bennet, R. W. (1996), Atypical toxigenic Staphylococcus and Non-Staphylococcus aureus species on the horizon? Na update. J. Food Protec. 59, 1123-1126.

Bergdoll, M. S. (1995), Importance of staphylococci that produce nanogram quantities of enterotoxin. ZBL. Bakt., 282, 1-6.

Bergdoll, M. S. (1979), Staphylococcal enterotoxin. In: Riemann, H. and Bryan, F. L. (eds.). Foodborne infections and intoxications. New York : Academic Press. pp. 443-494.
Bergdoll, M. S. (1989), Staphylococcus aureus. In: Doyle, M. P. (ed.). Foodborne Bacterial Pathogens, New York : Marcel Dekker. Inc. pp. 463-523.

Carmo,L. S. and Bergdoll, M. S. (1990), Staphylococcal food poisoning in Belo Horizonte (Brazil). Rev. Microbiol., 21, 320-323.

Carmo,L. S.; Dias, R. S.; Anunciação, L. L. C. and Bergdoll, M. S. (1995), Staphylococcal food poisoning in Minas Gerais state (Brazil). Arq. Brasil. Med. Vet., 47, 113-122.

Carmo, L. S.; Vieira, V.; Reis, J.; Pereira, M. L.; Santos, E. J. and Bergdoll, M. S. (1996), Staphylococcus aureus and Salmonella enteritidis present in food implicated in food poisoning. Rev. Microbiol., 27, 122-125.

Cerqueira-Campos, M. L.; Furlanetto, S. M. P.; Iaria, S. T. and Bergdoll, M. S. (1993), Staphylococcal food poisoning outbreaks in São Paulo (Brazil). Rev. Microbiol., 24, 261-264.

Dias, R. S.; Carmo, L. S. and Silva, M. C. C. (1999), Surto de toxinfecção alimentar causado pela ação simultânea de enterotoxina estafilocócica e Salmonella enteritidis - Estudo de caso. Rev. Inst. Adolfo Lutz., 58, 7-11.

Evenson, M. L.; Hinds, M. W.; Bernstein, R. S. and Bergdoll, M. S. (1988), Estimation of human dose of staphylococcal enterotoxin A from a large outbreak of staphylococcal food poisoning envolving chocolate milk. Int. J. Food Microbiol., 7, 311-316.

Genigeorgis, C. (1989), Present state of knowledge on staphylococcal enterotoxin. Int. J. Food Microbiol., 9, 327-360.

Iaria, S. T.; Furllanetto, S. M. P. and Campos, M. L. C. (1980), Pesquisa de Staphylococcus aureus enterotoxigênico nas fossas nasais de manipuladores de alimentos em hospitais. Rev. Saúde Pública., 14, 93-100

Lancette, G. A. and Tatini, S. R. (1992), Staphylococcus aureus. In: eds Vanderzant, C. and Splittstoesser, D. F. (eds.). Compendium of methods for the microbiological examination of foods. Washington : American Public Health Association. pp. 533-550.

Lotter, L. I. and Genigeorgis, C. A. (1977), Isolation of coagulase-negative enterotoxigenic cocci. Appl. Microbiol., 28, 152-158.

Mori, M.; Kato, E. and Hamada, S. (1977), Distribution of enterotoxigenic staphylococci in healthy food handlers and biological properties of isolates. Japan J. Bacteriol., 32, 501-508.

Oliveira Santos, B.; Aguillar, M. and Tanaka, O. M. U. (1990), Behavior of Staphyloccus aureus strains from simultaneous areas of healthy carriers working in different nursing category in a general teaching hospital. Rev. Microbiol., 21, 309-310. 
Pereira, M. L.; Carmo, L. S.; Lara, M. A.; Silva, S. O.; Dias, R. S. and Bergdoll, M. S. (1994), Enterotoxigenic Staphylococci from food handlers working in an industrial kitchen in Belo HorizonteMG (Brazil) Rev. Microbiol., 25, 161-165.

Robbins, R.; Gould, S. and Bergdoll, M. S. (1974), Detecting the enterotoxigenicity of Staphylococcus aureus strains. Appl. Microbiol., 28, 946-950.

Tatini, R. S.; Hoover, D. G. and Lachica, R. V. F. (1984), Methods for the isolation and enumeration of Staphylococcuc aureus. In: Speck, M. L. (ed.). Compendium of Methods for the Microbiological Examination of Foods. Washington : American Public Health Association Inc. pp. 411-427.

Udo E. E.; Al-Bustan, M. A.; Jacob, L. E. and Chught, T. D. (1999), Enterotoxin production by coagulasenegative staphylococci in restaurant workers from Kuwait City may be a potencial cause of food poisoning. J. Med. Microbial., 48, 819-823.

Vanderzant, C. and Splittsoesser, D. F. (1992), Compendium of methods for the microbiological examination of foods. Am. Public Health Association. pp. 1100.

Vernozy-Rozand, C.; Mazuy, C.; Prevvot, G.; Lapeyre, C.; Bes, M.; Brun, Y. and Fleurette, J. (1996), Enterotoxin production by coagulase-negative stafilococci isolated from goalt's milk and cheese. Int. J. Food Microbiol., 30, 271-280. 